\title{
SELECTING EFFECTIVE CRITERIA OF PRIVATIZATION IN IRAN NEWSPRINT PAPER INDUSTRIES
}

\author{
Majid Azizi * \\ Associate professor, Faculty of Natural Resources, \\ University of Tehran, \\ Email: $\underline{\text { mazizi@ut.ac.ir }}$ \\ Mansoureh Azizpour \\ Graduate MS student, Faculty of Natural Resources \\ University of Tehran
}

\begin{abstract}
Privatization of Iran newsprint industry cause to increase of production and decrease of import. Recognition of effective criteria in newsprint privatization will accelerate privatization of the industry. Goal of the research is expedition of privatization in Iran newsprint industries by benefits, costs, opportunities and risks merits.

Analytical Hierarchy Process (AHP) has been applied to solve the problem, as well as questionnaires, pair wise comparisons of the matrices by the expects have been done in the research. The results show, decrease of budget deficiency and national debts (economic \& financial), limiting rules and heavy taxes (economic \& executive), encouragement possibility and absorption of foreign and internal investment (economic \& financial) and limiting regulative costs (economic \& financial) are the most important sub criteria regarding benefits, costs, opportunities and risks merits, respectively.

Keywords: Newsprint paper, AHP, Criteria, Priority
\end{abstract}

\section{Introduction}

Paper industry is very important and strategic industry in each country. One of recognizing way regard to development rate in any community is per capita consumption of the paper. In 1995 world consumption of the paper was 260 million ton which grouping of this amount was as follows: newsprint and printing \& writing papers 45 percent, 40 percent packaging \& paperboard paper, 15 sanitary and percent special papers. Growth Rate of the paper industry in the world is 4.1 percent so the industry has special situation among other industries.

World production of newsprint paper in 2007 was 38 million ton (FAO, 2007) which maximum amount has been produced by United States of America, Canada, China, Japan, Germany, and France. Successful experiences of South East Asian countries indicated Privatization of governmental firms and decrease of government role in economy cause to sustainable economic growth in the country. Newsprint paper is a main and important product in comparison with other industries as well as it has special location in press activities. Proper execution of privatization in the newsprint paper industry cause to increase of production amount. Acknowledgement of the criteria which affect on accelerating news print paper privatization and transfer of these criteria to the producers will accelerate Iran newsprint industry privatization. Alex et al (2009) announced privatization is a major tool for economic reforming. Benefits of privatization in public section which is controlled by private section will procure maximum productivity and value via proper controlling from private section and receiving of cyclical moneys. Prokopenko (2001) believes the first goal of privatization is increase of effectiveness of national economy that is certain and proper way to reason of the goals and proportionate of the goals with public requests.

Goal of the study is presentation of a model of BOCR structure in privatization of Iran newspaper industry.

\footnotetext{
${ }^{*}$ Corresponding author
} 


\section{Analytic Hierarchy process}

The AHP for decision making is a theory of relative measurement based on paired comparisons used to derive normalized absolute scales of numbers whose elements are then used as priorities (Saaty, 1980 and 2000). Metrics of pair wise comparisons are formed either by providing judgments to estimate dominance using absolute numbers form the 1 to 9 fundamental scales of the AHP or by directly constructing the pair-wise dominance ratio using actual measurements. The AHP can be applied to both tangible and intangible criteria based on the judgments of knowledgeable and expert individuals. Although how to get measure for intangibles is its main concern. The weighting and adding model of synthetic process applied in the hierarchy structure of the AHP combines multidimensional scales of measurement to a single "uni-dimensional" scale of priority. Finally, we must fit our entire word experience into our system of priorities if we going to understand it (Saaty, 2007). To evaluate importance of privatization factors, the authors conduced a three-phased study, including:(1) identifying the elements (criteria and sub-criteria) and planning a hierarchy model for prioritization.(2) constructing the questionnaire and collecting of information. (3) Determining the normalized weights. Opinions coming from different experts including managers and specialists engineers in paper making and privatization were collected via carefully designed questionnaires and then synthesized and analyzed using an AHP software device.

\section{BOCR Structure}

To categorize the criteria which have been used in current research we divided them as favorable and unfavorable categories. The decision maker considers the favorable criteria as benefits and the unfavorable criteria as costs. The possible events are also divided into opportunities and risks criteria, depending whether they are considered to be positive or negative (Saaty, 2001). These criteria have been selected by managers and specialists infields of privatization and papermaking who were 60 percent from privatization experts and 40 percent were included paper making experts.

\section{o Benefits of acceleration of privatization process in Iran ne ws print paper industry}

Major criteria for accelerating privatization of Iran newsprint paper

Economic: financial, executive, trading and technology

- Financial:- decrease of budget deficiency and national debts

- Increase of production and productivity

- Executive: - adjustment of subsides and decrease price changing

-gathering cash flow and generation of a discipline for regular income distribution

- Increase of competition via price discipline release

- Trading: - extend of capital marketing

- More ability in newsprint paper export

- Link to WTO (world trade organization)

- Technology: flexibility in production lines of newsprint paper

Social: executive, operative and trading

- executive: - providence of consumers benefits

-decrease of governmental section size

- operative: - generation of liking and motivation in man force

- trading : - presentation of solution for prevention of trade problems

Technological: technology: - accessible to last know ledge and modern technology - Use of recycle of newsprint paper industry 


\section{o Costs of accele ration of privatization process in Iran ne ws print paper industry}

Economic: - executive: limiting rules \& heavy taxes

Social :- working: - decrease in employment

$$
\text { - Reduction of occupational security }
$$

\section{o Opportunities of accele ration of privatization process in Iran newsprint paper industry}

Economic: - financial: encouragement possibility and absorption of foreign and internal investment - executive: - competition possibility with fore ign newsprint paper products

$$
\text { - Quantitative development possibility of newsprint paper units }
$$

Social: - executive: revolution probability in legal relations of the society and structures

- Marketing: - absorption and keeping the customer from other countries

- Quick and on time response to customer's requirement

- Employment: occupation generation in long term

Technological: technology: utilization possibility from accomplishments of technologic

\section{Q Risks of accele ration of privatization process in Iran ne wsprint paper industry}

Economical: - financial: limiting regulative costs

- Marketing: limiting demand and poor financial markets

security: inconsistency and uncertainty of national economy

Social: - working: - generation of social disturbance due to unemployment in short term negative effect on employee's spirit and work moral

- executive: - interested groups opposition

- Opposition of managers and employees

- skillful nesses weakness of management in marketing economy

Cultural: - security: public jealousy to private entrepreneurships

\section{Results}

Table 1: Final outcome regard to benefits (Inconsistency ratio: 0.06)

\begin{tabular}{|l|l|l|}
\hline Main criteria & Sub criteria & $\begin{array}{l}\text { Weighing } \\
\text { value }\end{array}$ \\
\hline $\begin{array}{l}\text { Economic }(0.672) / \text { fin ancial } \\
(0.427)\end{array}$ & $\begin{array}{l}\text { Decrease of bud get deficiency and } \\
\text { national debts }\end{array}$ & 0.189 \\
\hline $\begin{array}{l}\text { Economic }(0,672) / \text { fin ancial } \\
(0.427)\end{array}$ & $\begin{array}{l}\text { Increase of production and } \\
\text { productivity }\end{array}$ & 0.184 \\
\hline $\begin{array}{l}\text { Economic }(0.672) / \text { executive } \\
(0.257)\end{array}$ & $\begin{array}{l}\text { Adjustment of subsides and decrease } \\
\text { price changing }\end{array}$ & 0.113 \\
\hline Economic $(0.672) /$ trading $(0.195)$ & Extend of capital marketing & 0.086 \\
\hline $\begin{array}{l}\text { Economic }(0.672) / \text { executive } \\
(0.257)\end{array}$ & $\begin{array}{l}\text { Gathering } \\
\text { cash flow and generation of a } \\
\text { discipline for regular income } \\
\text { distribution }\end{array}$ & 0.073 \\
\hline
\end{tabular}




\begin{tabular}{|l|l|l|}
\hline & & \\
\hline $\begin{array}{l}\text { Economic (0.672)/ executive } \\
(0.257)\end{array}$ & $\begin{array}{l}\text { Increase of competition via price } \\
\text { discipline release }\end{array}$ & 0.07 \\
\hline $\begin{array}{l}\text { Economic }(0.672) / \text { technology } \\
(0.122)\end{array}$ & $\begin{array}{l}\text { Flexibility in production lines of } \\
\text { newsprint paper }\end{array}$ & 0.054 \\
\hline Technological $(0.182) /$ technology & $\begin{array}{l}\text { Accessible to last knowledge and } \\
\text { modern technology }\end{array}$ & 0.051 \\
\hline Economic $(0.672) /$ trading $(0.195)$ & $\begin{array}{l}\text { Link to WTO (world trade } \\
\text { organization) }\end{array}$ & 0.044 \\
\hline Economic $(0.672) /$ trading(0.195) & More ability in newsprint paper export & 0.044 \\
\hline Social $(0.147) /$ executive $(0.257)$ & Providence of consumers benefits & 0.041 \\
\hline Social $(0.147) /$ operation $(0.223)$ & $\begin{array}{l}\text { Generation of liking and motivation in } \\
\text { man force }\end{array}$ & 0.015 \\
\hline Technological (0.182)/technology & $\begin{array}{l}\text { Use of recycle of newsprint paper } \\
\text { industry }\end{array}$ & 0.014 \\
\hline Social $(0.147) /$ trading $(0.166)$ & $\begin{array}{l}\text { Presentation of solution for prevention } \\
\text { of trade problems }\end{array}$ & 0.011 \\
\hline Social $(0.147) /$ executive $(0.223)$ & Decrease of governmental section size & 0.09 \\
\hline
\end{tabular}

Table 2: Final outcome regard to costs (inconsistency ratio: 0.00)

\begin{tabular}{|l|l|l|}
\hline Main criteria & Sub criteria & Weighing value \\
\hline Economic $(0.769) /$ executive & Limiting rules and heavy taxes & 0.614 \\
\hline Social $(0.231) /$ working & Decrease in employment & 0.201 \\
\hline Social $(0.231) /$ working & Reduction of occupational security & 0.186 \\
\hline
\end{tabular}

Table 3: Final outcome regard to opportunities (inconsistency ratio: 0.08)

\begin{tabular}{|l|l|l|}
\hline Main criteria & Sub criteria & Weighing value \\
\hline Economic (0.661)/ fin ancial (0.769) & $\begin{array}{l}\text { Encouragement possibility and } \\
\text { absorption of foreign and } \\
\text { internal investment }\end{array}$ & 0.375 \\
\hline Social $(0.217) /$ executive (0.403) & $\begin{array}{l}\text { Revolution probability in legal } \\
\text { relations of the society and } \\
\text { structures }\end{array}$ & 0.123 \\
\hline Social $(0.217) /$ marketing $(0.386)$ & $\begin{array}{l}\text { Absorption and keeping the } \\
\text { customer from other countries }\end{array}$ & 0.118 \\
\hline $\begin{array}{l}\text { Economic }(0.661) / \text { executive } \\
(0.231)\end{array}$ & $\begin{array}{l}\text { Competition possibility with foreign } \\
\text { newsprint paper }\end{array}$ & 0.113 \\
\hline Social $(0.217) /$ marketing $(0.386)$ & $\begin{array}{l}\text { Quick and on time response to } \\
\text { customer's requirement }\end{array}$ & 0.083 \\
\hline Technological (0.123)/ technology & $\begin{array}{l}\text { Utilization possibility from } \\
\text { accomplishments of technologic }\end{array}$ & 0.070 \\
\hline Social $(0.217) /$ employment $(0.211)$ & Occupation generation in long term & 0.065 \\
\hline $\begin{array}{l}\text { Economic }(0.661) / \text { executive } \\
(0.231)\end{array}$ & $\begin{array}{l}\text { Quantitative development } \\
\text { possibility of newsprint paper units }\end{array}$ & \\
\hline
\end{tabular}

Table 4: Final outcome regard to risks (inconsistency ratio: 0.05)

\begin{tabular}{|l|l|l|}
\hline Main criteria & Sub criteria & Weighing value \\
\hline Economic (0.663)/ fin ancial (0.436) & Limiting regulative costs & 0.289 \\
\hline Economic (0.663)/ security (0.361) & $\begin{array}{l}\text { Inconsistency and uncertainty of } \\
\text { national economy }\end{array}$ & 0.239 \\
\hline Social (0.233)/working & $\begin{array}{l}\text { Generation of social disturbance } \\
\text { due to unemployment in short term }\end{array}$ & 0.148 \\
\hline $\begin{array}{l}\text { Economic }(0.663) / \text { marketing } \\
(0.202)\end{array}$ & $\begin{array}{l}\text { Limiting demand and poor } \\
\text { financial markets }\end{array}$ & 0.134 \\
\hline Cultural (0.104)/ security & $\begin{array}{l}\text { Public jealousy to private } \\
\text { entrepreneurships }\end{array}$ & 0.104 \\
\hline Social $(0.233) /$ working $(0.792)$ & Negative effect on employee's spirit & 0.037 \\
\hline
\end{tabular}




\begin{tabular}{|l|l|l|}
\hline & and work moral & \\
\hline Social $(0.233) /$ executive $(0.208)$ & Interested groups opposition & 0.019 \\
\hline Social $(0.233) /$ executive $(0.208)$ & $\begin{array}{l}\text { Opposition of managers and } \\
\text { employees }\end{array}$ & 0.018 \\
\hline $\begin{array}{l}\text { Social }(0.233) \\
\text { / executive }(0.208)\end{array}$ & $\begin{array}{l}\text { Skillful nesses weakness of } \\
\text { management in marketing } \\
\text { economy }\end{array}$ & 0.012 \\
\hline
\end{tabular}

\section{Discussion}

Results show regard to benefits, economic criteria is the most important factor which influence on privatization of newsprint paper in the country. Regard to economic criteria (subsection of Trading), joint to world trade organization (0.582), (subsection of Financial) decrease of budget deficiency and national debts $(0.506)$ and (subsection of Executive) adjustment of subsides and decrease price changing (0.442) have the highest priority. One of the reasons to accelerate privatization in Iran is adjoining to WTO (world trade organization). After adjoining WTO, competition with other firms will occur which produce the same product so increase in production, quality and profitability are obtainable. By applying privatization rules, amount of the import and exit of foreign exchange from the country decrease also with converting low income and productivity firms to private section, economy productivity of the firms will improve and national debts reduce. Of course result of final processing (inconsistency ratio 0.06) indicates decrease of budget deficiency and national debts (weighing value: 0.189 ) has the highest priority among 15 sub criteria of benefits (see table1). Reviewing privatization program of Canada paper industry show the industry has reached to big successes via converting low efficiency paper units to private sections (Mooj news agency, 2007).

With respect to technology, subsection of technological criteria, accessible to last knowledge and modern technology has higher priority in comparison with use of use of recycle of newsprint paper industry. In paper industry to raise efficiency and increase in high quality paper production, we have to use newest technology until the product obtains competition possibility with foreign papers in the country. One of the main paths to use of modern technology is joining WTO. Privatization of the industry cause to increase in production volume and productivity, so the industry cans response to requirements of the customers in the future. For this reason, result of final processing (inconsistency ratio: 0.00) indicated, regard to economic criteria (subsection of Financial), increase of production and productivity sub criteria of has the second priority (0.184). Prokopenko (2001) believes the first goal of privatization is increase of effectiveness of national economy and this subject is very compatible with increasing productivity of the firms as the most important sub criteria. Davis (2000) researches showed privatization improve financial situation of public sections, which is compatible with result of current research, decrease of budget deficiency and national debts as the highest priority sub criteria.

With respect to costs, economic criteria (0.769) has the highest priority in comparison with social criteria (0.231). Final result (inconsistency ratio: 0.00) shows regard to economic criteria (sub section of executive), limiting rules \& heavy taxes $(0.614)$ has the highest priority which indicates legislation has important function in newsprint paper industry (see table 2). Newsprint paper and pulp in Canada is free from heavy customs tariffs, for this reason the industry obtains high profit every year (Moj news agency, 1998). Limiting rules \& heavy taxes has preventive role to execute privatization process in Iran newsprint paper industry and heavy customs tariffs is one of this rules. Decrease in employment (subsection of social) has second priority (0.201) with respect to costs criteria. Psychological and economical significance of decrease in employment is very important due to mental and financial influences on man force.

Economic criteria has highest priority (0.661) regard to opportunities. Final processing (inconsistency ratio: 0.08) shows encouragement possibility and absorption of foreign and internal investment sub criteria (subsection of financial) with weighing value 0.375 has highest priority (see table3). Privatization of newsprint paper industry needs high assets to supply high costs of machines and modern technology. Privatization generate proper opportunity for the investors until they can solve their problems via absorption of foreign and internal investment which lead to technology transfer of built, planning, research and development. Revolution probability in legal relations of the society and structures $(0.123)$ has obtained second priority. Kind of management has high effect on behavior of the employers. Privatization with changing ownership and management will improve customary structure in the industry. Regard to social criteria (subsection of marketing) absorption and keeping the customer from other countries has third 
priority (0.118). Privatization carries out successfully in product marketing via absorption of customers and new investors and keeping present customers. Actually via capital absorption, improving and accelerating privatization procedure will be done more quickly in the newsprint paper industry.

Concerning results in part of risks economic criteria (0.663) has more priority in comparison with social and cultural criteria. After final synthesizing (inconsistency ratio: 0.05), regard to economic criteria (subsection of financial), limiting regulative costs (0.289) has the highest priority (see table4). Privatization of paper industry in Canada shows these kinds of costs are preventive factor to execute privatization procedure (Mooj news agency, 2007). Once more in part of economical criteria, Inconsistency and uncertainty of national economy (subsection of security) has second priority (0.239). Change of foreign currency in internal marketing is one of the most important economic risks for foreign investment in the country. Intense change of foreign currency cause to capital loss of foreign investors who had opportunity to invest in the country. In part of social criteria (subsection of working) generation of social disturbance due to unemployment in short term has third priority (0.148). Privatization cause to deposal of man force and decrease in employment in short term, at the same time social welfare will reduce and generate negative effect on man force spirit. Finally the situation leads to social disturbance.

\section{Conclusion}

For developing Iran newspaper industry and increasing its production BOCR structure has been used. After identifying the effective criteria and obtaining opinions of the experts the results have been calculated by AHP and Expert Choice software. The results shows in parts of Benefits, Costs, Opportunities and Risks, Decrease of budget deficiency and national debts, Limiting rules and heavy taxes, Encouragement possibility and absorption of foreign and internal investment, and Limiting regulative costs have highest priorities respectively.

\section{REFERNCES}

Davis, C. 2000, privatization: common themes, similar outcomes, available at: www.edu.umn FAO, 2007, www. faostate.fao.org

Mooj news agency, 2007, www.paperandwood.com

$\mathrm{Ng}$ A., Yuce A., Chen E., 2009, Determinate of state equity ownership and effect on value/ performance: China's privatized firms, Pacific - Basin Finance Journal 17, 413-443.

Prokopenko J., 2001, Management of privatization, Davari D. \& Akbari, H., Ariana industrial research center (Translation in Farsi)

Saaty T., 2001. Decision Making with Dependence and Feedback: The Analytic Network Process, RWS Publications, Pittsburgh, PA.

Satty, T.L., 1980, “The analytic Hierarchy Process", McGraw-Hill international. New York, RWS publications, Pitts burgh

Satty, T.L., 2000, "Fundamentals of Decision Making with Analytic Hierarchy Process", paperback, RWS publications, 4922 Ellsworth Avenue, Pittsburgh, PA 15213-2807

Saaty, T.L., 2007, "Time dependent decision-making; dynamic priorities AHP/ANP: Generalizing from points to functions and from real to complex variables", Mathematical and Computer modeling, $46,860-891$ 